\title{
From facilitation to competition: the effect of black locust (Robinia pseudoacacia L.) on the growth performance of four poplar-hybrids (Populus spp.) in mixed short rotation coppice
}

\author{
Jessica Rebola-Lichtenberg ${ }^{1,2}$ D . Juliane Streit ${ }^{2,3,4} \cdot$ Peter Schall $^{1}$. \\ Christian Ammer ${ }^{1,2}$. Dominik Seidel ${ }^{1}$
}

Received: 24 February 2020 / Accepted: 7 October 2020 / Published online: 21 October 2020

(c) The Author(s) 2020

\begin{abstract}
Short rotation coppices play an important role in providing biomass for energetic use. Mixing fast-growing tree species in short rotation coppices may show complementarity effects and increased yield. The aim of this study was to analyze the effect of species interaction in mixed short rotation coppices with fast-growing Populus spp.-hybrids and the N-fixing Robinia pseudoacacia. Four different Populus-hybrids (AF2, Fritzi Pauley, Hybride 275 and Max 1), planted alternately in pure and mixed stands with $R$. pseudoacacia were used for the analysis. Height and root collar diameter were measured once a year, over a period of four years (2014-2017). Additionally, in the third year, aboveground competition was surveyed with a terrestrial laser scanner and root biomass was analyzed to assess belowground competition. Soil nitrogen was also determined in order to verify enrichment properties of mixtures compared to pure stands. Populus-hybrids' stem volume showed no significant differences between stand types in the first year after planting. In the second and third year, however, two Populus-hybrids (AF2 and Max 1) had a higher stem volume increment of up to 3.8 times than stem volume increment in pure stands. This may be related to the fact that soil nitrogen was $39 \%$ higher in the mixtures than in pure stands. However, in the 4th year after stand establishment, $R$. pseudoacacia's crowns were so massive and broad, that this species was far more competitive than the Populus-hybrids. With the exception of $P$. 'Fritzi Pauley', which showed no significant differences between stand types, growth rates reversed for the other three Populus-hybrids. AF2, Max 1 and Hybride 275 showed up to $75 \%$ lower stem volume increment in mixtures compared to pure stands. We assume that, in spite of the initially observed facilitation between the species, the competition exerted by $R$. pseudoacacia started dominating after 4 years and began to surpass the benefits of facilitation.
\end{abstract}

Keywords Short rotation coppice $\cdot$ SRC $\cdot$ Poplar $\cdot$ Black locust $\cdot$ Competition $\cdot$ Facilitation

Jessica Rebola-Lichtenberg

jessica.rebola-lichtenberg@forst.uni-goettingen.de

Extended author information available on the last page of the article 


\section{Introduction}

Wood production contributes to natural decarbonisation and subsequent climate change mitigation (Canadell and Raupach 2008; Knust 2009; Parikka 2004). As a renewable source of energy, wood has great potential as a fossil fuel substitute (Demirbas 2001). In fact, the use of woody biomass increased in Germany (Ewald et al. 2017; Gößwein et al. 2018) while cultivation in short rotation coppices rather stagnated (Wühlisch 2016). However, intensifying wood production in SRC on agricultural lands would alleviate pressure on forests and reduce the impact of extensive agricultural management on biodiversity (Butler Manning et al. 2015; Harris et al. 2017; Schmidt and Glaser 2009). Short rotation coppices (from here on referred to as SRC) are typically high-density, single-species plantings of fast-growing trees with rotation lengths of less than 20 years (Knust 2009; Stanturf and Oosten 2014). Poplar hybrids (Populus spp.) and black locust (Robinia pseudoacacia L.) are two of the most often planted tree species in SRC for energy purposes in Germany (Knust et al. 2013). Populus hybrids planted in SRC in Germany can reach 6-14 $\mathrm{t} \mathrm{ha}^{-1}$ year $^{-1}$ of dry wood matter and $R$. pseudoacacia yields around 3-10 t ha $\mathrm{ha}^{-1} \mathrm{year}^{-1}$ in rotation periods of 3 to 10 years depending on site and water availability (Knust et al. 2013). The genus Populus primarily grows on moist sites like fluvial plains with seasonal flooding (Knust et al. 2013; Rennenberg et al. 2010; Richardson et al. 2014). Populus nigra L. and Populus deltoides W.Bartram ex Marschall grow mainly along rivers, streams and flood plains. Populus trichocarpa ToRR \& A.GRAY EX HooK grows on a wide range of soils and topography, but also prefers soils along riverbanks. Populus maximowiczii A.Henry grows along mountain rivers and streams with annual rainfall ranges from 600 to $1400 \mathrm{~mm}$ (Richardson et al. 2014). In contrast to Populus sp., Robinia pseudoacacia does not occur in wetlands or alluvial forests. Instead, it commonly occurs in areas with 480-800 mm rainfall per year (Vítková et al. 2017). In central Europe, Robinia pseudoacacia, is preferably planted in regions with poor precipitation and low nutrient availability (Knust 2009; Rédei 2013). R. pseudoacacia is not only less demanding regarding water and nutrients than Populus sp., but also, as a legume tree species, has the ability to fix nitrogen and enhance soil fertility (Binkley 1992; Kanzler et al. 2020; Knust 2009; Nicolescu et al. 2018; Veste et al. 2013).

Tree species combinations with complementary ecological traits might have the potential of higher yield compared to monocultures (Pretzsch and Forrester 2017). In forest stands, both reduction in competition and facilitation have been identified as underlying processes (Forrester and Bauhus 2016). Competition reduction occurs if interspecific competition is lower than intraspecific interference, while facilitation can be observed if one species positively influences another species (Ammer 2019). For instance, mixing $\mathrm{N}$-fixing tree species may be beneficial for neighboring individuals of nitrogen-demanding species (Forrester et al. 2006; Hansen and Dawson 1982; Marron and Epron 2019). Indeed, Oliveira et al. (2018) and Rédei et al. (2006) were able to prove that mixing $R$. pseudoacacia to white poplar (Populus alba) can increase, under certain circumstances, Populus' biomass growth. However, another study on Populus spp. ('Dorskamp', Populus deltoides $\times$ Populus nigra) and $R$. pseudoacacia mixed SRC found no advantage regarding biomass growth (Gana 2016). Thus, the traits that trigger and determine differences in productivity in mixed Populus sp. and $R$. pseudoacacia SRC have not yet been fully understood.

Pretzsch (2017a) pointed out the importance of studying mixing effects on an individual tree level in order to better understand "competition, competition reduction through 
complementarity, and facilitation", as mixing influences the environmental conditions resulting in altered tree and stand growth. It is well known that canopy structure affects light interception and carbon assimilation, which in turn have an impact on stand productivity (Broeckx et al. 2012; Forrester et al. 2018; Ishii et al. 2004; Kim et al. 2011). As a result individual tree growth is strongly depending not only on the proximity but also on the identity of the surrounding neighborhood (Fichtner et al. 2017; Metz et al. 2019; Pretzsch 2017a). Yet, it is not clear to what extent Populus-hybrids react differently, on the single-tree level, in mixed SRC with $R$. pseudoacacia.

In this study we hypothesized that Populus-hybrids in mixed stands with an N-binding legume tree like $R$. pseudoacacia would have an advantaged growth in comparison to monospecific stands. In addition, we addressed the following questions in order to assess the impact on Populus-hybrids at a single-tree level: (1) do the different Populus-hybrids react distinctly to the neighboring $R$. pseudoacacia in the first years of a recently established SRC? (2) does any of the Populus-hybrids and R. pseudoacacia have complementary ecological traits, which result in more efficient use of resources compared with monocultures?

\section{Materials and methods}

\section{Study site}

The plantation was established in April 2014 at the research farm of the Georg-AugustUniversity Göttingen in Reinshof $\left(51.484^{\circ} \mathrm{N} / 9.923^{\circ} \mathrm{E}\right)$, in the center of Germany in the state of Lower Saxony. Reinshof's soil is classified as Gleyic Fluvisol, a young fertile soil with high water storage capacity. During the study period rainfall was distributed very unevenly throughout the active growth period. Precipitation and mean temperature for the region of Göttingen were taken from the DWD ("Deutscher Wetterdienst-Climate Data Center," 2019) and can be seen on Table 1.

For this study, we analyzed four commercially used Populus hybrids: AF2 (P. deltoides $\times$ P. nigra), Fritzi Pauley (P. trichocarpa $\times$ P. trichocarpa), Hybride275 (P. maximowiczii $\times P$. trichocarpa) and Max 1 ( $P$. nigra $\times P$. maximowiczii $)$. As a complementary tree species for mixtures, we chose a single black locust provenance: Robinia pseudoacacia L., Northern German lowlands, HKG81901. Four planting blocks were established, each of which comprised one pure plot for each Populus hybrid, one $P$. hybrid/R. pseudoacacia mixed plot and one $R$. pseudoacacia pure plot (Fig. 1). On each plot, 25 trees were planted in a $1 \times 1 \mathrm{~m}$ spacing. Unrooted Populus spp. stem cuttings $(25 \mathrm{~cm}$ in length) and rooted $R$. pseudoacacia one year old nurslings were hand-planted. The $R$. pseudoacacia nurslings were cut down to the same size as Populus-hybrids stem cuttings right after planting.

The plantation was treated as a low-input system, i.e. no fertilizers or herbicides were applied. Instead, ground vegetation was mown in the second year in June and in the

Table 1 Total yearly precipitation $(\mathrm{mm})$ and mean temperature $\left({ }^{\circ} \mathrm{C}\right)$ for the region of Göttingen during the growing seasons of 2014 (1st year, stand establishment) until 2017 (4th year)

\begin{tabular}{lllll}
\hline Year & 2014 & 2015 & 2016 & 2017 \\
\hline$\varnothing^{\circ} \mathrm{C}$ & 10.6 & 10.1 & 9.82 & 9.85 \\
$\mathrm{~mm}$ & 609 & 627 & 544 & 777 \\
\hline
\end{tabular}


Fig. 1 Exemplary block comprising the different stand types (mixed and pure Populus spp.). The black squares represent the plots $(5 \times 5 \mathrm{~m})$ used for the competition survey. Aerial picture by Annika Ligner (IAPN, Göttingen), captured 26.7.2016

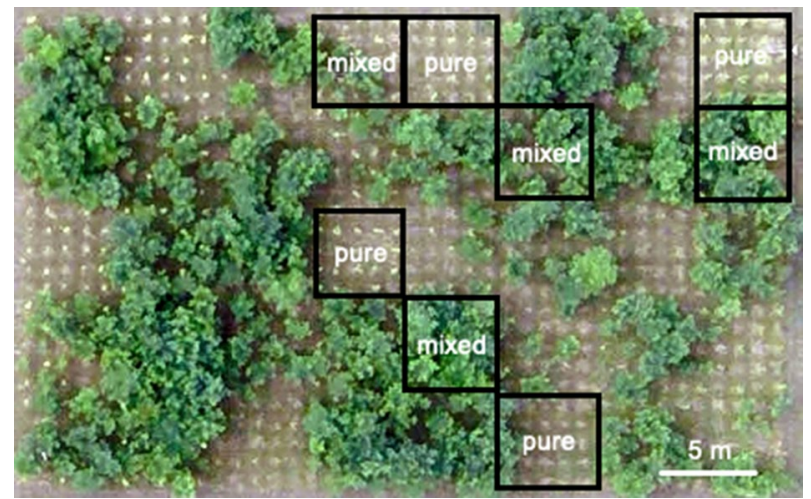

summer of the third year. There was no irrigation at any time. Mice control was carried out regularly to minimize rodent damage.

\section{Plant growth survey}

Height and root collar diameter were measured for each tree in-situ once a year while in dormancy. Height was measured using a measuring pole for bigger trees and a ruler for smaller $(<200 \mathrm{~cm})$ trees and root collar diameter was measured at $3 \mathrm{~cm}$ above ground using a digital calliper. Height was expressed in $\mathrm{cm}$ and diameter in $\mathrm{mm}$. Stem volume, was estimated using the simplified equation $V=D^{2} H$, with root collar diameter $D$ and height $H$ and expressed in $\mathrm{cm}^{3}$. $\mathrm{V}$ is known to be very closely related to woody biomass (Annighöfer et al. 2016). Volume increment of a specific year was analysed by subtracting the volume of the year before to the year being analysed and expressed in $\mathrm{cm}^{3}$ year ${ }^{-1}$. No volume increment was calculated for the first year, since the first measurement of the trees was done after the first growing season.

\section{Competition survey}

In the first two years after stand establishment there were no crown overlapping, so there was no measurable aboveground competition. In the third year, however, some crowns started overlapping. After the growing season in that year (in the Winter of 2016/2017) we conducted an aboveground competition survey to assess crown overlapping over Populus spp. trees. All 16 mixed plots and 16 pure Populus spp. plots were selected, resulting in a total of 32 surveyed plots. In every plot, we chose the Populus spp. tree that was planted centrally in order to minimize edge effects. A terrestrial laser scanner, Faro Focus 3D 120 (Faro Technologies Inc., Lake Marry, USA), was used to quantify the competition strength enforced on these trees. Therefore, we placed the scanner on a tripod at $1.3 \mathrm{~m}$ directly over the study trees while bending the study tree towards the ground (under the scanner level). We conducted a single scan at each tree, using a field of view of $180^{\circ}$ in vertical direction (upper hemisphere) and $360^{\circ}$ in horizontal direction. The scan resolution was set to 0.035 degrees and all objects within a distance of $120 \mathrm{~m}$ were captured. After transferring the scan data to the computer we used Faro Scene (Faro Technologies Inc., Lake Marry, USA) software to filter each scan for erroneous scan points (stray points, etc.) using the standard filters and filter settings of the software. Then, each scan was exported as xyz-file for 
further processing. Using an algorithm written in Mathematica (Wolfram Research, Champaign, USA) we applied a 1-cm point cloud grid to the data, homogenizing the data density to reduce effects of varying distance to the scanner (see Seidel et al. 2011 for details). Finally, we determined the aboveground competition enforced on each study tree by counting the number of laser hits in a vertically orientated, upward-facing search cone with 60 degree opening angle in accordance with Seidel et al. (2015). Some of the trees, that were initially selected, died after the survey and were excluded from the final analysis. In the end we had $\mathrm{n}_{\text {pure }}=15$ and $\mathrm{n}_{\text {mix }}=10$ Populus hybrids trees for the analysis.

\section{Root survey}

Belowground biomass of pure and mixed stands of the Populus 'Max 1' and R. pseudoacacia were studied. Since surveying roots is a very laborious and difficult work, we focussed on only one hybrid. We chose the hybrid that seemed to be most vital and fast-growing. Three plots (pure Populus spp., mixed and pure $R$. pseudoacacia) per block were assessed. Root sampling was conducted using a metal root auger $(2 \mathrm{~cm}$ diameter $)$ down to $30 \mathrm{~cm}$ soil depth in October 2016 (third year after planting). In each plot, a central tree with four neighboring trees was selected. Four soil samples per plot were taken mid-way between the central and the neighboring tree. Soil samples from three different soil layers $(0-10$, 10-20 and 20-30 cm) were transferred into plastic bags and stored separately at $4{ }^{\circ} \mathrm{C}$. In order to extract roots, soil samples were rinsed over a sieve (mesh size $0.4 \mathrm{~mm}$ ) using tap water and cleaned of soil residue. Coarse and fine roots were manually sorted into Populus, $R$. pseudoacacia and grass roots using a stereomicroscope by inspecting the root colour, elasticity, surface structure and mode of branching (Jacob et al. 2013; Kubisch et al. 2015). Root material was then dried at $55^{\circ} \mathrm{C}$ for $72 \mathrm{~h}$ until constant weight. Data was expressed as poplar (Populus spp. 'Max 1') and black locust ( $R$. pseudoacacia) and grass root biomass for 0-10, 10-20 and 20-30 $\mathrm{cm}$ soil depth per area in $\mathrm{mg} \mathrm{cm}^{-2}$.

In order to compare root development between pure and mixed stands we used the "nontransgressive" approach (Pretzsch 2005). A mixture shows over- or underyielding if its performance is greater or lower than expected based on the weighted average of the monoculture outcomes of the component species. It was calculated as:

$$
\Delta p_{r e l}=\left[\frac{p_{1,2}}{\left(m_{1} p_{1}+m_{2} p_{2}\right)}-1\right] \cdot 100
$$

where $p_{1,2}$ was total root biomass in mixtures. $p_{1}$ and $p_{2}$ are the total root biomass in pure culture for Populus spp. 'Max 1' and R. pseudoacacia and $m_{1}$ and $m_{2}$ are the proportions of both tree species in mixtures (in our case 0.5 ). Results are expressed in percentage (\%).

\section{Nitrogen analysis}

Soil cores for nitrogen analysis were sampled using a metal soil auger ( $2 \mathrm{~cm}$ diameter) in October 2016 (3 years after planting). Three random samples per plot were taken down to $30 \mathrm{~cm}$ soil depth. Soil samples were transferred into plastic bags and stored at $-18{ }^{\circ} \mathrm{C}$. For the analysis, $100 \mathrm{~g}$ of soil was diluted in $250 \mathrm{ml}$ of $0.01 \mathrm{M} \mathrm{CaCl}_{2}$ solution and shaken for one hour at room temperature. After filtration, the content of soil mineral nitrate and ammonium of the solution was determined photometrically (AutoAnalyzer 3 SEAL, Norderstedt, Germany). The gravimetric soil water content was determined 
by drying the soil samples for $24 \mathrm{~h}$ at $105{ }^{\circ} \mathrm{C}$. Data was expressed as total soil nitrogen $\left(\mathrm{N}_{\text {total }}=\mathrm{NH}_{4}{ }^{+}+\mathrm{NO}_{3}{ }^{-}\right)$for $0-30 \mathrm{~cm}$ soil depth averaged over plots in $\mathrm{kg} \mathrm{ha}^{-1}$.

\section{Statistical and data analysis}

All statistical analyses were conducted using the R software version 3.5.1 (R Development Core Team 2018, Vienna, Austria). Stem volume, diameter and height of the trees were analysed on single-tree level. Root biomass and $\mathrm{N}_{\text {total }}$ where analysed on the plot level using stand type as explanatory variable in linear models (ANOVA). All data compared was normal distributed. First we compared the variances by using Fisher's F test. In case of lack of significance we used ANOVA to compare the differences between the stand types. If the variance was significantly different, we applied the Welch Test. The relationship between Populus-hybrids height increment and competition was analyzed using linear regression.

\section{Results}

\section{Tree growth}

In the first year after planting, Populus spp. stem volume did not differ between stand types: mean volume was $39 \mathrm{~cm}^{3}$ for trees in mixed and in pure stands (Fig. 2). In the second year, a significantly higher stem volume was registered for Populus in the mixtures $\left(132 \mathrm{~cm}^{3}\right)$ compared to pure stands $\left(95 \mathrm{~cm}^{3}\right)$ (Fig. 2), which corresponds to a higher stem volume in mixtures of $39 \%$. In the third year, the pattern of an advanced increment in mixtures persisted. Similar to the year before, Populus' trees had an overall $43 \%$ higher stem volume in mixtures (Fig. 2).

The degree of the effect on the four hybrids, however, differed. In the third year after stand establishment, Populus height in particular was, for 3 out of 4 Populus hybrids, significantly higher in mixtures than in pure stands. Only Fritzi Pauley showed no significant differences between stand types (Fig. 3). AF2 showed a 66\% and Max 1 a 30\% higher annual stem volume increment in mixtures than in pure stands (Fig. 4). Fritzi Pauley and Hybride 275 showed, however, no significant differences between the means for annual stem volume increment of the different stands (Fig. 4).

In the 4th year after stand establishment, however, growth relations reversed. Populus trees annual mean stem volume increment in mixtures was in general $44 \%$ lower than in pure stands $\left(4638 \mathrm{~cm}^{3}\right.$ year $^{-1}$ in pure and $3066 \mathrm{~cm}^{3}$ year ${ }^{-1}$ in mixed stands) (Figs. 2, 3). The recess in stem development was particularly high for the hybrid AF2 (Fig. 4). Its annual mean stem volume increment in pure stands was over four times higher than in pure stands (Fig. 4). Also, for Hybride275 and Max 1 annual stem volume increment was significantly lower in mixed than in pure stands (42\% and 53\% respectively) (Fig. 4). Populus spp. 'Fritzi Pauley', once again, didn't show any significant difference between the stands (Figs. 3, 4). The R. pseudoacacia showed advantaged growth in comparison to the Populus hybrids (Fig. 3e). In the third year, as crowns started overlapping, R. pseudoacacia trees were between 26\% (for Max 1) and 73\% (for Fritzi Pauley) higher than Populus spp. trees (Fig. 3). 

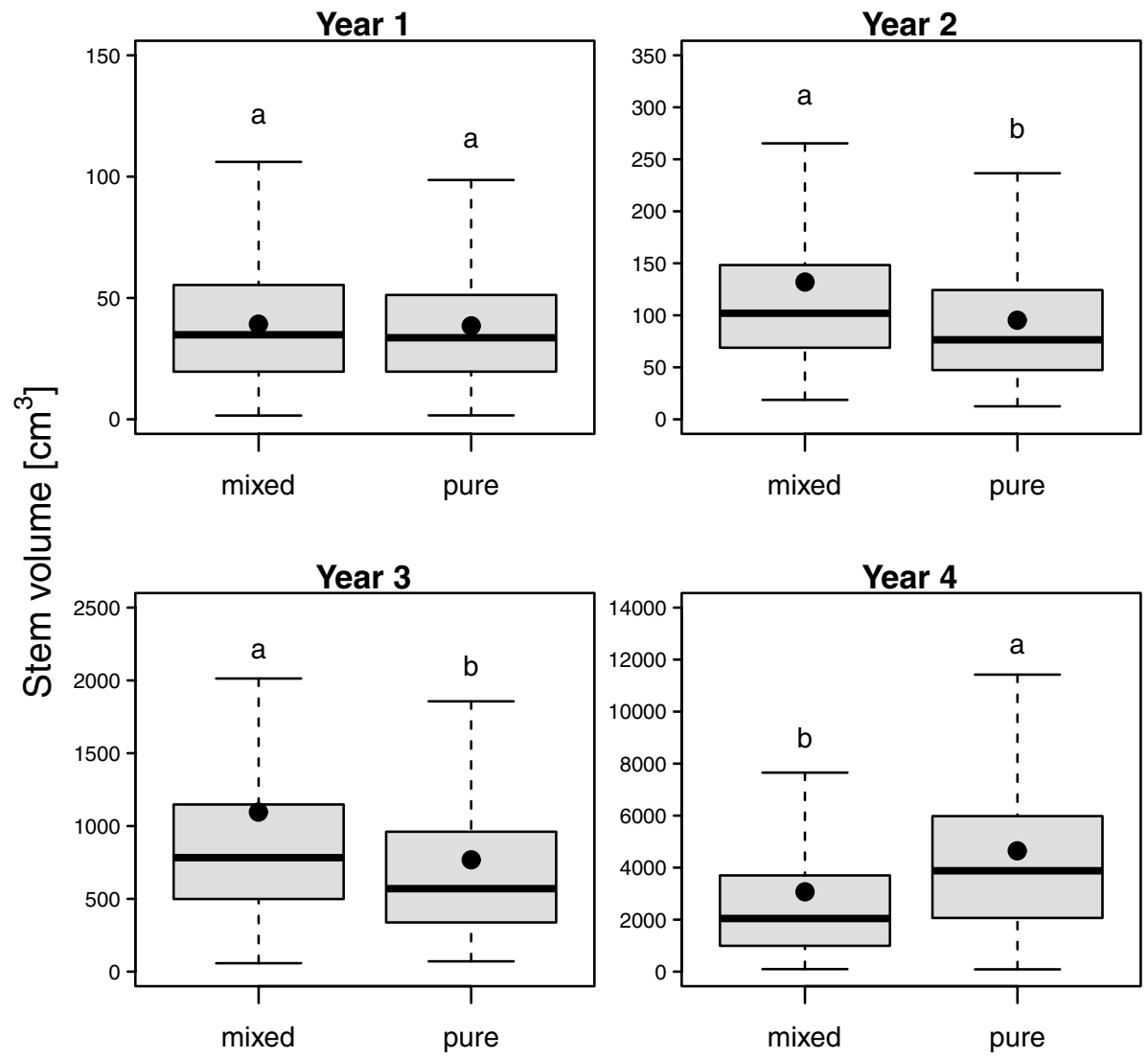

Fig. 2 Stem volume per Populus tree $\left(\mathrm{cm}^{3}\right)$ across all hybrids for the first 4 years after stand establishment in mixed and pure stands. Mean values are marked by black dots. Solid lines in the boxes represent the median, the bottom and the top of the box represent first and third quartile (IQR). Each whisker represents 1.5 IQR. Different letters (a, b) indicate significant differences between the stand types at significance level $p<0.05$

\section{Competition effects}

Populus hybrids in mixtures were exposed to a much higher aboveground competition in mixed than in pure stands (6306.80 voxels in mixtures and 57.47 voxels in pure stands, $p<0.005)$. A strong negative correlation was found between height and root collar diameter increment of Populus hybrids in the 4th year after stand establishment with increasing competitive pressure (Fig. 5).

\section{Roots and nitrogen content in the soil}

The means of total root biomass at a soil depth of $0-30 \mathrm{~cm}$ for Robinia pseudoacacia and Populus spp. 'Max 1' differed significantly between pure and mixed stands. $R$. pseudoacacia's total root biomass was, in both mixed and pure stands, approximately 

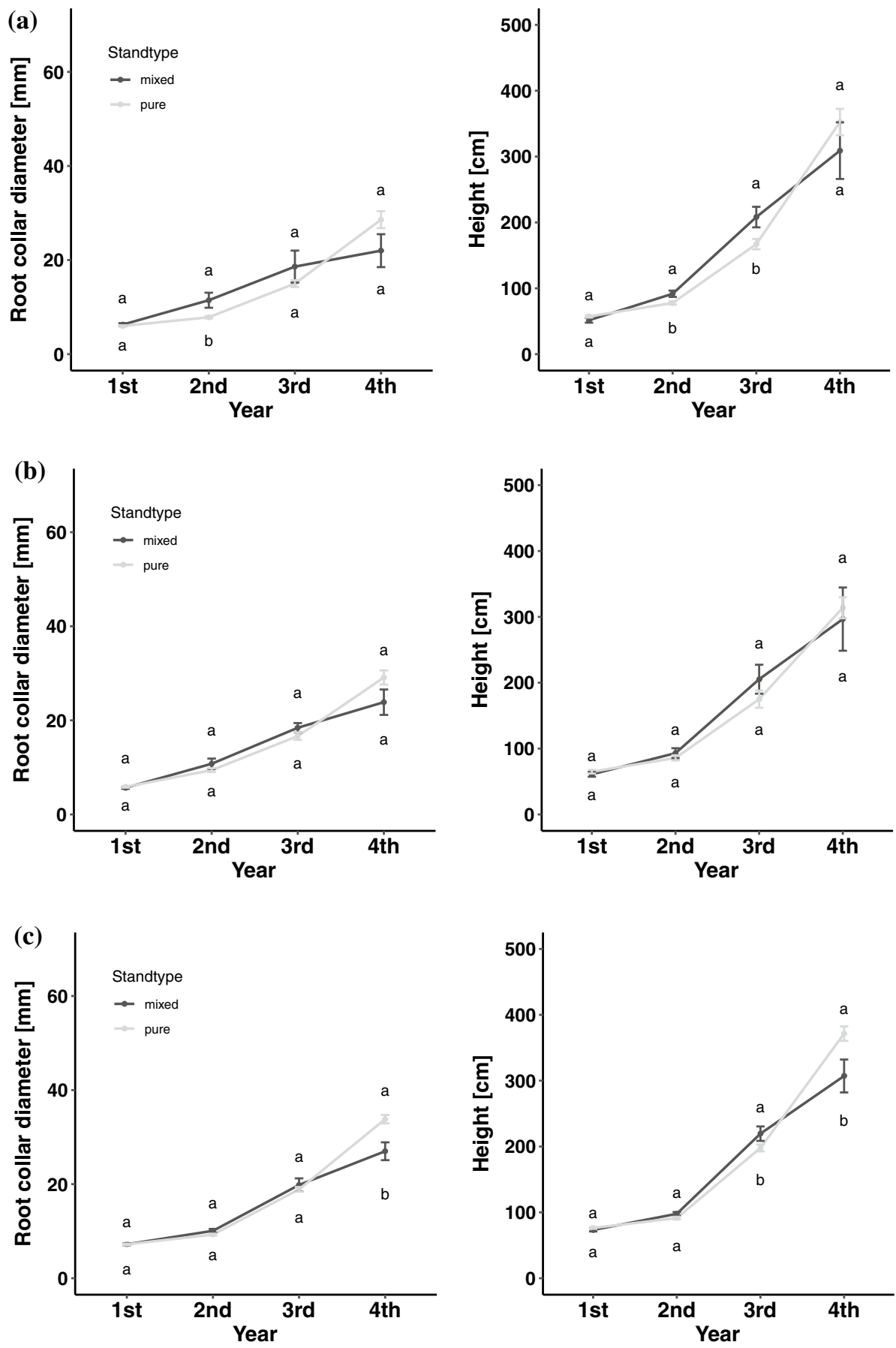

Fig. 3 Progression of root collar diameter $(\mathrm{mm})$ and height $(\mathrm{cm})$ of the different Populus hybrids and the $R$. pseudoacacia over a period of 4 years in mixtures and in pure stands. Error bars represent standard error of the means. Different letters $(a, b)$ represent significant differences between mixed and pure stands for each year 

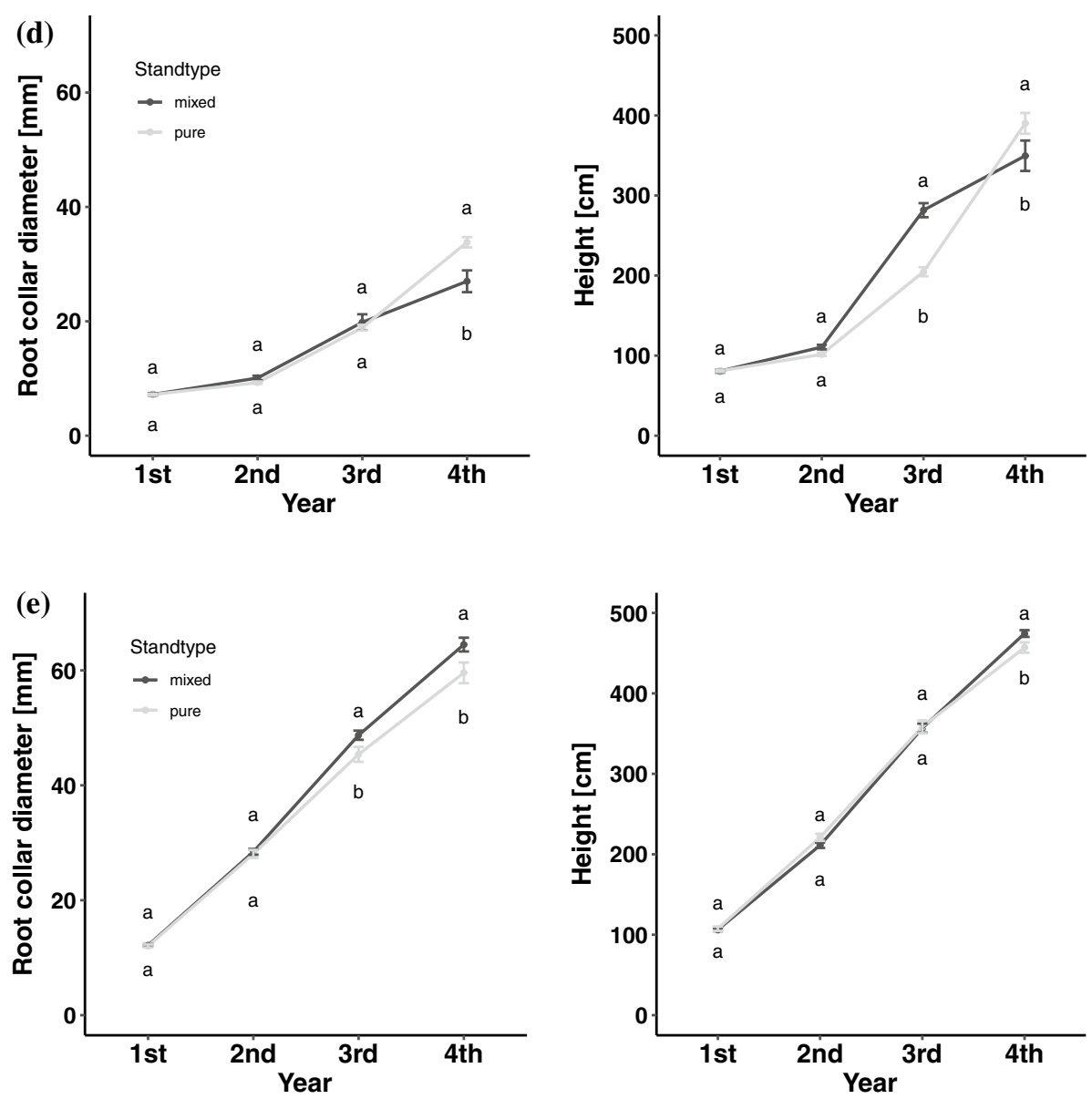

Fig. 3 (continued)

three times higher than that of Populus. Root biomass of all species declined with depth (Fig. 6). The total root biomass dropped substantially in mixtures reflecting an underyielding. The mean of $R$. pseudoacacia's total root biomass per plot was $1.13 \mathrm{mg} \mathrm{cm}^{-2}$ in pure stands and $0.44 \mathrm{mg} \mathrm{cm}^{-2}$ in mixed stands, Populus hybrids' root biomass was $0.40 \mathrm{mg} \mathrm{cm}^{-2}$ in pure and $0.14 \mathrm{mg} \mathrm{cm}^{-2}$ in mixed stands. $R$. pseudoacacia's root biomass $\left(\Delta \mathrm{p}_{\mathrm{rel}}\right)$ dropped $22 \%$ and Populus spp. 'Max 1' $30 \%$. Grass roots predominated each stand type at every soil depth (Fig. 6), but no significant differences were found between the stand types for the total grass root biomass.

The total soil nitrogen content $\left(\mathrm{N}_{\text {total }}\right)$ in the third year significantly differed between stand types $(p<0.05)$ : pure Populus stands had the lowest $\mathrm{N}_{\text {total }}$ content $\left(5.4 \mathrm{~kg} \mathrm{ha}^{-1}\right)$, followed by mixed stands $\left(7.5 \mathrm{~kg} \mathrm{ha}^{-1}\right)$. R. pseudoacacia's stands had the highest $\mathrm{N}_{\text {total }}$ content with $10.3 \mathrm{~kg} \mathrm{ha}^{-1}$. 

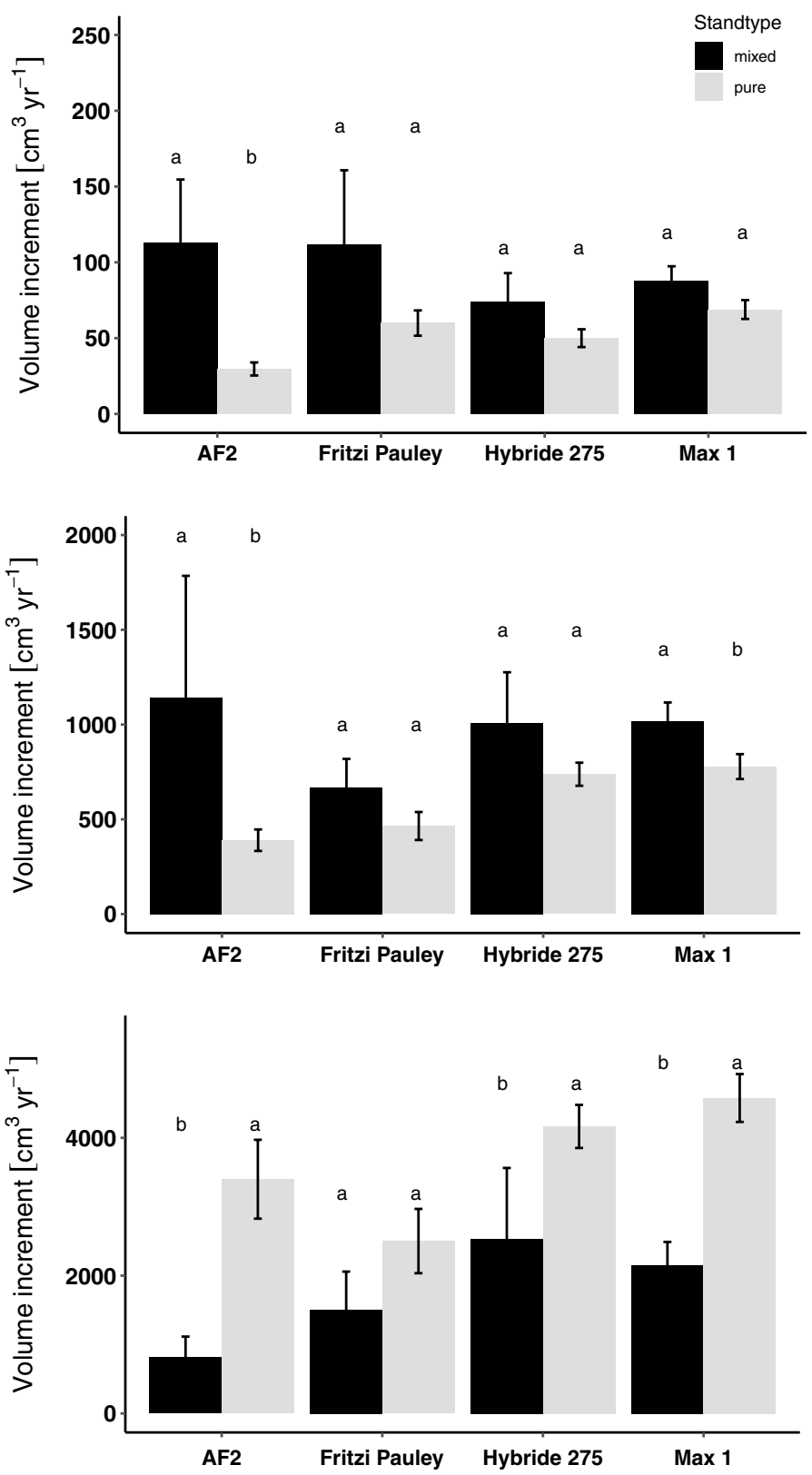

Fig. 4 Mean tree stem volume increment per year $\left(\mathrm{cm}^{3}\right.$ year $\left.{ }^{-1}\right)$ for the different Populus hybrids in mixed and in pure stands. Error bars represent standard error of the means. Different letters $(\mathrm{a}, \mathrm{b})$ represent significant differences between mixed and pure stands for each Populus hybrid 
(a)

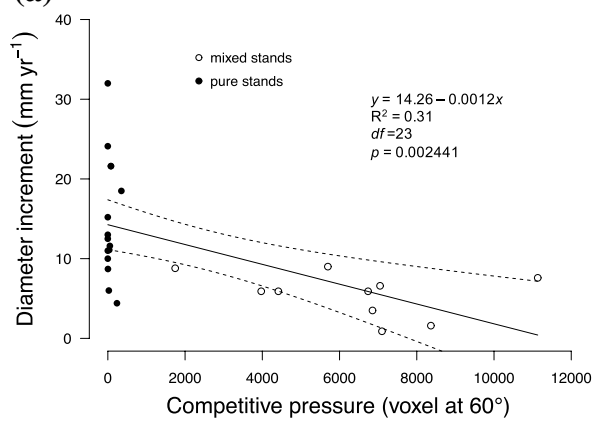

(b)

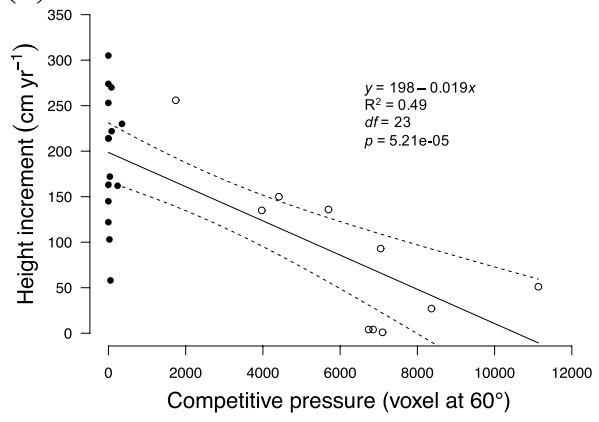

Fig. 5 a Relation between Populus' hybrids root collar diameter increment (mm year $\left.{ }^{-1}\right)$ in the 4 th year and the competitive pressure caused by neighboring trees (number of voxels in $60^{\circ}$ cone); $\mathbf{b}$ Relation between Populus' hybrids height increment $\left(\mathrm{cm} \mathrm{year}^{-1}\right)$ in the same year and the competitive pressure. Both plotted with $95 \%$-confidence interval, $\mathrm{n}=25$

\section{Discussion}

Our recently established mixed stands of Populus hybrids and $R$. pseudoacacia showed that interactions between the tree species are dynamic and vary as stand develops. While in the first years the positive mixing effects on Populus hybrids were predominant, canopy closure, negatively affected the growth performance of the hybrids. This outcome may explain contrasting findings of past studies addressing this kind of mixture. While facilitation and increased yield in mixed culture of Populus sp. and R. pseudoacacia were observed by some authors (Oliveira et al. 2018; Rédei et al. 2006), others showed no facilitation or even strong interspecific competition (Gana 2016; Marron et al. 2018). Our main hypothesis, which stated that Populus hybrids with an N-binding legume tree like R. pseudoacacia would have an advantaged growth compared to Populus hybrids in monoculture, could not be completely disproved nor confirmed. Positive and negative interactions between species probably occurred simultaneously (D'Amato and Puettmann 2004; Forrester 2017), varying spatially and temporally depending on resource availability, climatic conditions (Forrester 2017) and stand development (Forrester et al. 2004; Pretzsch and Forrester 2017). Our study suggests, that the predominant process of interaction, very much depends on the point in time at which the stands are investigated.

\section{Facilitation}

The objective of admixing the legume tree Robinia pseudoacacia with Populus hybrids was to increase the $\mathrm{N}$ availability to the SRC-system and promote higher growth of the $\mathrm{N}$ demanding species Populus sp.. Successful combinations of N-fixing with N demanding tree species in short-rotation plantings was already reported by Forrester et al. (2004) with Eucalyptus globulus and Acacia mearnsii and by Hansen and Dawson (1982) with Alnus glutinosa and Populus-hybrids.

Our experiment showed that on the second and third year after stand establishment, Populus' single tree stem volume was significantly higher in mixture than in pure stands (Fig. 2). Looking closely at the different hybrids (Fig. 3, Fig. 4), we observe that degree of 


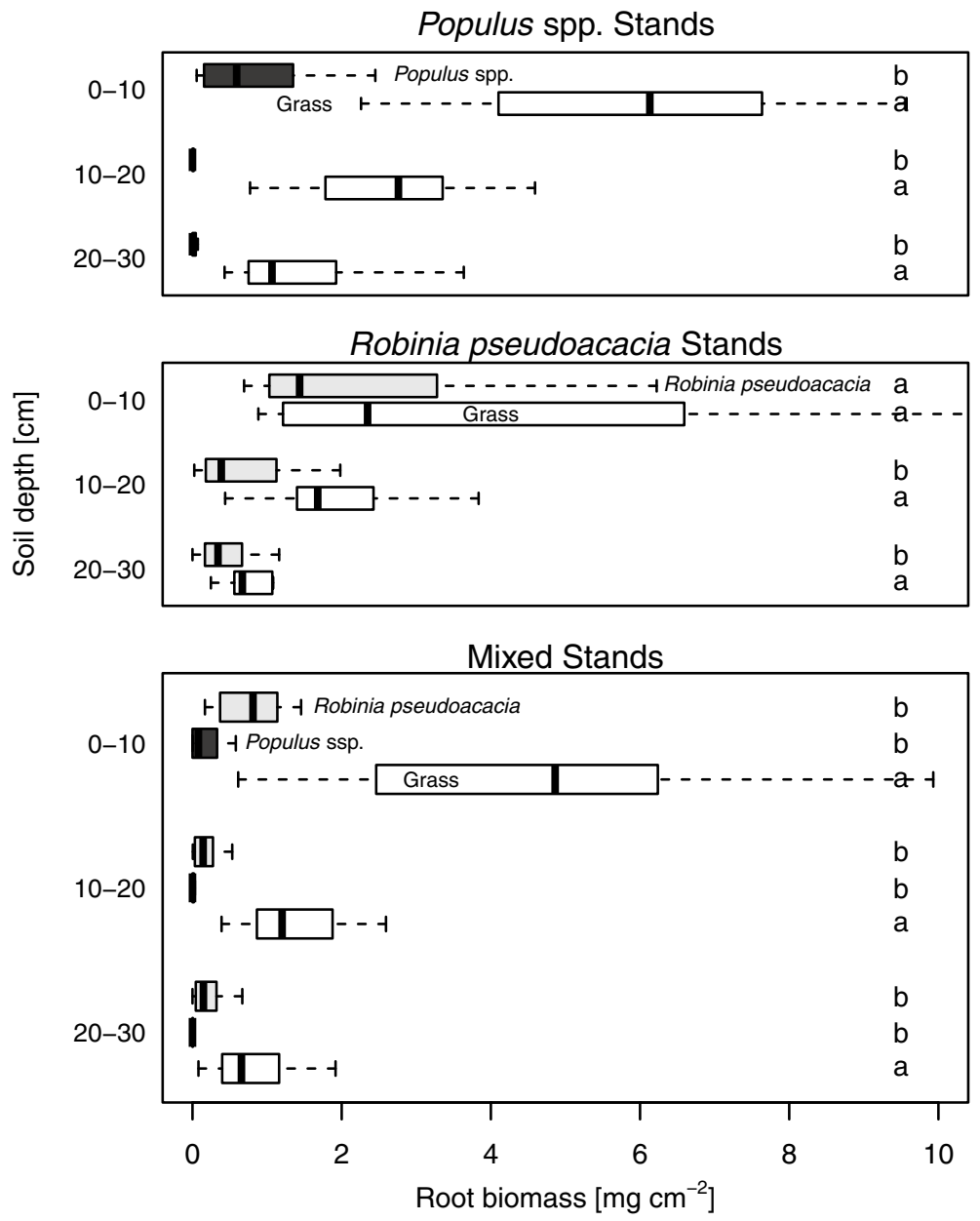

Fig. 6 Root biomass distribution at different soil depths $(0-10,10-20$ and 20-30 cm) in pure and mixed stands of black locust (Robinia pseudoacacia) and poplar (Populus spp. 'Max 1') in the 3rd year after stand establishment. Different letters (a, b) indicate significant differences between the species (black locust, poplar and grass) in the stands at the given soil depth (significance level $p<0.05$ )

the effect of interspecific facilitation was distinct between the different hybrids. Facilitation was most obvious for AF2, which showed an advantaged stem volume increment in the mixtures in the second and third year of respectively 3.8 and 3 times more than stem volume increment in pure stands (Fig. 4). Max 1 showed only in the third year a 1.3 times faster growth in mixtures compared to pure stands (Fig. 4). Even though Hybride275 and Fritzi Pauley showed a tendency for higher growth in mixtures at the same period of time, the differences were not significant (Fig. 4). Populus hybrids are known for taking up N rapidly from the soil resulting in higher growth rates (Cooke et al. 2005; Liu and Dickmann 1993). In the context of SRC, $\mathrm{N}$ fertilization is used to improve harvest yields and reduce rotation age (Cooke et al. 2005; Rennenberg et al. 2010). In our case, it is likely that presence of $R$. pseudoacacia led to an increase in $\mathrm{N}$ availability for the hybrids. In fact, in the third year after stand establishment, $\mathrm{N}_{\text {total }}$ was $39 \%$ higher in mixtures than in pure Populus 
stands. Since no fertilizer was added in our study, we assume that $R$. pseudoacacia led to a "natural" fertilization of the soil. This facilitation effect continued into the third year after stand establishment and seemed to confirm the findings of Marron and Epron, (2019), who stated that mixed tree plantations with $\mathrm{N}$-fixing tree species are generally more productive $(24 \%)$ than monocultures under temperate conditions.

\section{Aboveground competition}

The mode of interaction between trees in forests is predominantly the competition for resources (D'Amato and Puettmann 2004). Mixing ecologically complementary species can increase the inequality of size and growth distribution between small and tall trees (Pretzsch 2017b) and differences in size among trees in their early growth rates may increase as stands develop (D'Amato and Puettmann 2004). Negative mixing effects due to inequal growth distribution was observed in young mixed plantations of red alder (Alnus rubra Bong.) with Douglas-fir (Pseudotsuga menziesii Franco) (Radosevich et al. 2006) and of Pinus radiata with Acacia spp. (Forrester et al. 2007). Indeed, our study shows, that 4 years after stand establishment, the effects of competition enforced on the Poриlus hybrids by $R$. pseudoacacia began to surpass the benefits of the facilitation (Fig. 2). After the third year, crown cover in the mixtures was on average more than a 100 times higher than in pure Populus stands (Fig. 5). R. pseudoacacia's crowns were so massive and broad, that they were far more competitive than Populus trees. Three (out of four) Populus hybrids, therefore, reversed growth rates (Fig. 3), by showing a significantly lower stem volume increment in mixed stands in comparison to pure stands (Fig. 4). The hybrid AF2 had the highest negative impact, by growing in mixtures only $1 / 4$ of the growth in pure stands. The hybrids Max 1 and Hybride 275 reduced growth in mixtures to around half of the growth in pure stands. Oliveira et al. (2018) showed that SRC mixture of R. pseudoacacia and white poplar (Populus alba) had a notable influence on yield: Populus alba, however, only showed overyielding in mixtures if the proportion of $R$. pseudoacacia was lower (25\%). Our experiment had a mixture proportion of $50 \%$. The high density of $R$. pseudoacacia, with a strong canopy cover (Fig. 5) and their presumably well distributed roots (Fig. 6) led to increased competition over Populus and subsequently to a regression on height (Figs. 3, 5b) and diameter (Figs. 3, 5a) increment of the latter. The genus Рориlus belongs to the fastest growing trees in the temperate zone, but their high productivity depends on high water availability and full sunlight (Monclus et al. 2006; Stanturf and Oosten 2014; Stettler and Bradshaw 1996; Vítková et al. 2017). In addition, highly productive hybrids used in SRC usually have a low level of drought tolerance (González-González et al. 2017; Monclus et al. 2006). For a successful seedling growth it is recommended to irrigate the plantation in the first year after planting (Knust et al. 2013). The fact that our experiment was implemented as a low-input-system very likely resulted in Populus trees struggling with water scarcity, since there was no irrigation at any time. When soil water is restricted, photosynthesis of high-N demanding plants like Populus is also restricted (Liu and Dickmann 1993; Mitchell 1992). In contrast, the much more drought resistant $R$. pseudoacacia was able to outcompete, at a very young stage, all four Populus hybrids and, at some point, suppressed the growth of three out of four hybrids. Not even Populus spp. 'Max 1', which is considered to be highly productive and drought resistant (Euring et al. 2016; Schildbach et al. 2012), was able to compete with $R$. pseudoacacia. This findings give the answer to our first research question: do the different Populus-hybrids react distinctly to the neighboring $R$. pseudoacacia? Populus spp. 'Fritzi Pauley', didn't show, at 
any time, significant differences in its growth compared to monospecific stands. All other three Populus-hybrids showed in first place positive mixing effects followed by negative effects due to competition. The intensity of the impact varied slightly between the different hybrids, but none of them stood out. In an earlier paper, we could show that the mortality of Populus-hybrids was higher if planted at the same time in mixed stands with R. pseudoacacia than in pure plots (Rebola-Lichtenberg et al. 2019), which underpins the high dominance and competitiveness of $R$. pseudoacacia in a low-input-system.

\section{Belowground competition}

Root development affect availability of nutrients and have considerable influence on growth (Mitchell 1992) but is not a reliable indicator of Populus' aboveground biomass (Al Afas et al. 2008). In our experiment, the biomass of the peripheral root system, where tree roots of both tree species were expected to get into contact, dropped significantly in the mixtures for both species, indicating belowground underyielding. While this result could rather be expected for Populus from the findings on the lower annual stem increment in mixtures, it was unexpected for $R$. pseudoacacia. In fact, we expected belowground overyielding of $R$. pseudoacacia. A potential explanation may be that the competition by grass was much higher in the mixed plots than in the pure $R$. pseudoacacia plots (Fig. 6). Nevertheless, $R$. pseudoacacia's root biomass in mixtures was less reduced than Populus' in comparison to pure stands, highlighting the competitive ability of $R$. pseudoacacia not only aboveground, but also belowground. Finally, we can answer our second research question, whether at least one of the Populus-hybrids have complementary ecological traits with $R$. pseudoacacia. Even though there seems to be positive mixing effects between both species that could enhance Populus growth, the competition is, under a low-input system and a mixing species ratio of 50:50, too high for any of the Populus-hybrids to be able to compete. Hence, there is no clear sign of long-term facilitation or competition reduction for any of the Populus-hybrids.

\section{Conclusions}

The variability we observed in the mixing responses is the evidence that there is a risk in prematurely generalizing mixing effects found in short-term experiments (Pretzsch and Forrester 2017). From a management point of view our results have important implications. Given that there was facilitation in the beginning of our experiment, future studies should explore options to reduce the competition by $R$. pseudoacacia on time, but only to a degree that ensures a positive net effect. Oliveira et al. (2018) reduced the amount of $R$. pseudoacacia trees successively, which may be a plausible solution. In practical terms, planting designs should take into account that $R$. pseudoacacia develops large crowns exerting strong aboveground competition. Planting $R$. pseudoacacia in rows with greater distance to Populus trees, would reduce the competition while maintaining a certain level of natural nitrogen enrichment of the soil. Another option may be the delayed planting of the N-fixing species a few years after planting Populus (Radosevich et al. 2006). It is well known from other studies that delayed planting can help to control competition between tree species that differ in their growth pattern (Radosevich et al. 2006). Furthermore, the probability of drought episodes and more severe climatic events is increasing (Lindner et al. 2010; Monclus et al. 2006). The productivity of European forests is therefore expected to decline, 
resulting in yield reduction (Lindner et al. 2010). Against this background the mixture of the drought resistant $R$. pseudoacacia and the fast-growing Populus sp. is, even though our study pointed towards some trade-offs, still a promising SRC mixture, which needs to be further studied.

Acknowledgements This research was funded by the German Federal Ministry of Education and Research (BMBF) within the framework of the IMPAC ${ }^{3}$ project. We would like to thank Michael Unger, Michael Reichel and Marco Winkler for supervising the plantation, Dr. Jasmin Seven, Dr. Marco Gronwald, Johanna Ropertz, Dr. Dejuan Euring, Dr. Oleksandra Kuchma, Dr. Kirsten Höwler and Ulrike Westphal for helping with the fieldwork, Andreas Parth for helping with the data entry and all students involved with field and laboratory work: Julia Heike Schubert, Andreas Wintraken, Lennard Siek, Torben Tomforde, Wolf Benjamin Hansel, Jan-Marten Müller-Thomsen, Tarek Neubert, Ferdinand Bennighof and Michele Borga. We are grateful for the administrative support of this study by Prof. Dr. Horst-Henning Steinmann, Centre of Biodiversity and Sustainable Land Use.

Funding Open Access funding enabled and organized by Projekt DEAL.

Open Access This article is licensed under a Creative Commons Attribution 4.0 International License, which permits use, sharing, adaptation, distribution and reproduction in any medium or format, as long as you give appropriate credit to the original author(s) and the source, provide a link to the Creative Commons licence, and indicate if changes were made. The images or other third party material in this article are included in the article's Creative Commons licence, unless indicated otherwise in a credit line to the material. If material is not included in the article's Creative Commons licence and your intended use is not permitted by statutory regulation or exceeds the permitted use, you will need to obtain permission directly from the copyright holder. To view a copy of this licence, visit http://creativecommons.org/licenses/by/4.0/.

\section{References}

Al Afas N, Marron N, Zavalloni C, Ceulemans R (2008) Growth and production of a short-rotation coppice culture of poplar-IV: fine root characteristics of five poplar clones. Biomass Bioenergy 32:494-502. https://doi.org/10.1016/j.biombioe.2007.11.007

Ammer C (2019) Diversity and forest productivity in a changing climate. New Phytol 221:50-66. https:// doi.org/10.1111/nph.15263

Annighöfer P, Ameztegui A, Ammer C, Balandier P, Bartsch N, Bolte A, Coll L, Collet C, Ewald J, Frischbier N, Gebereyesus T, Haase J, Hamm T, Hirschfelder B, Huth F, Kändler G, Kahl A, Kawaletz H, Kuehne C, Lacointe A, Lin N, Löf M, Malagoli P, Marquier A, Müller S, Promberger S, Provendier D, Röhle H, Sathornkich J, Schall P, Scherer-Lorenzen M, Schröder J, Seele C, Weidig J, Wirth C, Wolf H, Wollmerstädt J, Mund M (2016) Species-specific and generic biomass equations for seedlings and saplings of European tree species. Eur J For Res 135:313-329. https://doi.org/10.1007/s1034 2-016-0937-z

Binkley D (1992) Mixtures of nitrogen2-fixing and non-nitrogen2-fixing tree species. The ecology of mixed-species stands of trees. Blackwell Scientific Publications, Oxford, pp 92-123

Broeckx LS, Verlinden MS, Vangronsveld J, Ceulemans R (2012) Importance of crown architecture for leaf area index of different Populus genotypes in a high-density plantation. Tree Physiol 32:1214-1226. https://doi.org/10.1093/treephys/tps083

Butler Manning D, Bemmann A, Bredemeier M, Lamersdorf N, Ammer C (2015) Bioenergy from dendromass for the sustainable development of rural areas. Wiley, Weinheim

Canadell JG, Raupach MR (2008) Managing forests for climate change mitigation. Science 320:1456-1457. https://doi.org/10.1126/science.1155458

Cooke JEK, Martin TA, Davis JM (2005) Short-term physiological and developmental responses to nitrogen availability in hybrid poplar. New Phytol 167:41-52. https://doi.org/10.1111/j.1469-8137.2005.01435 . $\mathrm{x}$

D'Amato A, Puettmann K (2004) The relative dominance hypothesis explains interaction dynamics in mixed species Alnus rubra/Pseudotsuga menziesii stands. JSTOR 92:450-463

Demirbaş A (2001) Biomass resource facilities and biomass conversion processing for fuels and chemicals. Energy Convers Manag 42:1357-1378. https://doi.org/10.1016/S0196-8904(00)00137-0 
Deutscher Wetterdienst-Climate Data Center [WWW Document] (2019) Deutscher Wetterdienst-Climate Data Center. www.DWD.de. Accessed 7.15.19

Euring D, Ayegbeni S, Jansen M, Tu J, Gomes Da Silva C, Polle A (2016) Growth performance and nitrogen use efficiency of two Populus hybrid clones $(P$. nigra $\times P$. maximowiczii and $P$. trichocarpa $\times P$. maximowiczii) in relation to soil depth in a young plantation. iForest 9:847-854. https://doi.org/10.3832/ ifor2016-009

Ewald J, Rothe A, Hansbauer MM (2017) Energiewende und Waldbiodiversität: Abschlussbericht zum F+E-Vorhaben "Energiewende und Waldbiodiversität." BfN-Skripten, Bundesamt für Naturschutz, Bonn-Bad Godesberg

Fichtner A, Härdtle W, Li Y, Bruelheide H, Kunz M, von Oheimb G (2017) From competition to facilitation: how tree species respond to neighbourhood diversity. Ecol Lett 20:892-900. https://doi.org/10.1111/ ele. 12786

Forrester DI (2017) Ecological and physiological processes in mixed versus monospecific stands. In: Pretzsch H, Forrester DI, Bauhus J (eds) Mixed-species forests: ecology and management. Springer, Berlin, pp 73-115

Forrester DI, Bauhus J (2016) A review of processes behind diversity-productivity relationships in forests. Curr For Rep 2:45-61. https://doi.org/10.1007/s40725-016-0031-2

Forrester DI, Bauhus J, Khanna PK (2004) Growth dynamics in a mixed-species plantation of Eucalyptus globulus and Acacia mearnsii. For Ecol Manag 193:81-95. https://doi.org/10.1016/j.forec o.2004.01.024

Forrester DI, Bauhus J, Cowie AL, Vanclay JK (2006) Mixed-species plantations of Eucalyptus with nitrogen-fixing trees: a review. For Ecol Manag 233:211-230. https://doi.org/10.1016/j.forec o.2006.05.012

Forrester DI, Bauhus J, Cowie AL, Mitchell PA, Brockwell J (2007) Productivity of three young mixedspecies plantations containing N2-fixing Acacia and non-N2-Fixing Eucalyptus and Pinus trees in Southeastern Australia. For Sci 53:426-434. https://doi.org/10.1093/forestscience/53.3.426

Forrester DI, Ammer C, Annighöfer PJ, Barbeito I, Bielak K, Bravo-Oviedo A, Coll L, del Río M, Drössler L, Heym M, Hurt V, Löf M, den Ouden J, Pach M, Pereira MG, Plaga BNE, Ponette Q, Skrzyszewski J, Sterba H, Svoboda M, Zlatanov TM, Pretzsch H (2018) Effects of crown architecture and stand structure on light absorption in mixed and monospecific Fagus sylvatica and Pinus sylvestris forests along a productivity and climate gradient through Europe. J Ecol 106:746-760. https://doi.org/10.1111/1365-2745.12803

Gana C (2016) Croissance, production et acquisition de l'azote chez le peuplier et le robinier en plantations à courte rotation monospécifiques et mélangées - $\mathrm{PhD}$-thesis

González-González BD, Oliveira N, González I, Cañellas I, Sixto H (2017) Poplar biomass production in short rotation under irrigation: a case study in the Mediterranean. Biomass Bioenergy 107:198206. https://doi.org/10.1016/j.biombioe.2017.10.004

Gößwein S, Hiendlmeier S, Borchert H (2018) Energieholzmarkt Bayern 2016. Abschlussbericht, LWF Freising, p 131

Hansen EA, Dawson JO (1982) Effect of Alnus glutinosa on hybrid Populus height growth in a shortrotation intensively cultured plantation. For Sci 28:49-59

Harris ZM, Alberti G, Viger M, Jenkins JR, Rowe R, McNamara NP, Taylor G (2017) Land-use change to bioenergy: grassland to short rotation coppice willow has an improved carbon balance. GCB Bioenergy 9:469-484. https://doi.org/10.1111/gcbb.12347

Ishii HT, Tanabe S, Hiura T (2004) Exploring the relationships among canopy structure, stand productivity, and biodiversity of temperate forest ecosystems. For Sci 50(3):342-355

Jacob A, Hertel D, Leuschner C (2013) On the significance of belowground overyielding in temperate mixed forests: separating species identity and species diversity effects. Oikos 122:463-473. https:// doi.org/10.1111/j.1600-0706.2012.20476.x

Kanzler M, Böhm C, Freese D (2020) The development of soil organic carbon under young black locust (Robinia pseudoacacia L.) trees at a post-mining landscape in eastern Germany. New For. https:// doi.org/10.1007/s11056-020-09779-1

Kim H-S, Palmroth S, Therezien M, Stenberg P, Oren R (2011) Analysis of the sensitivity of absorbed light and incident light profile to various canopy architecture and stand conditions. Tree Physiol 31:30-47. https://doi.org/10.1093/treephys/tpq098

Knust C (2009) Kurzumtriebsplantagen - Stand des Wissens. In: Anbau und Nutzung von Bäumen auf Landwirtschaftlichen Flächen. Blackwell, pp 1-9. https://doi.org/10.1002/9783527627462.ch1

Knust C, Schua K, Wolf H, Feger K-H (2013) Natürliche Rahmenbedingungen. In: Energieholzplantagen in Der Landwirtschaft. Agrimedia, pp 19-52 
Kubisch P, Hertel D, Leuschner C (2015) Do ectomycorrhizal and arbuscular mycorrhizal temperate tree species systematically differ in root order-related fine root morphology and biomass? Front Plant Sci 6:64. https://doi.org/10.3389/fpls.2015.00064

Lindner M, Maroschek M, Netherer S, Kremer A, Barbati A, Garcia-Gonzalo J, Seidl R, Delzon S, Corona P, Kolström M, Lexer MJ, Marchetti M (2010) Climate change impacts, adaptive capacity, and vulnerability of European forest ecosystems. For Ecol Manag 259:698-709. https://doi. org/10.1016/j.foreco.2009.09.023

Liu Z, Dickmann DI (1993) Responses of two hybrid Populus clones to flooding, drought, and nitrogen availability. II. Gas exchange and water relations. Can J Bot 71:927-938. https://doi.org/10.1139/ b93-104

Marron N, Epron D (2019) Are mixed-tree plantations including a nitrogen-fixing species more productive than monocultures? For Ecol Manag 441:242-252. https://doi.org/10.1016/j.forec o.2019.03.052

Marron N, Priault P, Gana C, Gérant D, Epron D (2018) Prevalence of interspecific competition in a mixed poplar/black locust plantation under adverse climate conditions. Ann For Sci. https://doi. org/10.1007/s13595-018-0704-z

Metz J, Annighöfer P, Westekemper K, Schall P, Schulze E-D, Ammer C (2019) Less is more: effects of competition reduction and facilitation on intra-annual (basal area) growth of mature European beech. Trees-Struct Funct. https://doi.org/10.1007/s00468-019-01894-7

Mitchell CP (1992) Ecophysiology of short rotation forest crops. Biomass Bioenergy 2:25-37. https:// doi.org/10.1016/0961-9534(92)90085-5

Monclus R, Dreyer E, Villar M, Delmotte FM, Delay D, Petit J-M, Barbaroux C, Le Thiec D, Bréchet C, Brignolas F (2006) Impact of drought on productivity and water use efficiency in 29 genotypes of Populus deltoides $\times$ Populus nigra. New Phytol 169:765-777

Nicolescu V-N, Hernea C, Bakti B, Keserú Z, Antal B, Rédei K (2018) Black locust (Robinia pseudoacacia L.) as a multi-purpose tree species in Hungary and Romania: a review. J For Res 29:14491463. https://doi.org/10.1007/s11676-018-0626-5

Oliveira N, del Río M, Forrester DI, Rodríguez-Soalleiro R, Pérez-Cruzado C, Cañellas I, Sixto H (2018) Mixed short rotation plantations of Populus alba and Robinia pseudoacacia for biomass yield. For Ecol Manag 410:48-55. https://doi.org/10.1016/j.foreco.2017.12.034

Parikka M (2004) Global biomass fuel resources. Biomass Bioenergy 27:613-620

Pretzsch H (2005) Diversity and productivity in forests: evidence from long-term experimental plots. In: Scherer-Lorenzen M, Körner C, Schulze E-D (eds) Forest diversity and function: temperate and boreal systems, ecological studies. Springer, Berlin, pp 41-64. https://doi.org/10.1007/3-540-26599 $-6 \_3$

Pretzsch H (2017a) Individual tree structure and growth in mixed compared with monospecific stands. In: Pretzsch H, Forrester DI, Bauhus J (eds) Mixed-species forests-ecology and management. Springer, Berlin

Pretzsch H (2017b) Size-structure dynamics in mixed versus monospecific stands. In: Pretzsch H, Forrester DI, Bauhus J (eds) Mixed-species forests-ecology and management. Springer, Berlin, pp 211-269

Pretzsch H, Forrester DI (2017) Stand dynamics of mixed-species stands compared with monocultures. In: Pretzsch H, Forrester DI, Bauhus J (eds) Mixed-species forests: ecology and management. Springer, Berlin, pp 117-209. https://doi.org/10.1007/978-3-662-54553-9_4

Radosevich SR, Hibbs DE, Ghersa CM (2006) Effects of species mixtures on growth and stand development of Douglas-fir and red alder. Can J For Res 36:768-782. https://doi.org/10.1139/x05-280

Rebola-Lichtenberg J, Schall P, Annighöfer P, Ammer C, Leinemann L, Polle A, Euring D (2019) Mortality of different Populus genotypes in recently established mixed short rotation coppice with Robinia pseudoacacia L. Forests 10:410. https://doi.org/10.3390/f10050410

Rédei K (2013) Black locust growing in Hungary. Hungarian Forest Research Institute, Sárvar

Rédei K, Veperdi I, Meilby H (2006) Stand structure and growth of mixed white poplar (Populus alba L.) and black locust (Robinia pseudoacacia L.) plantations in Hungary. Acta Silv Lign Hung 2:23-32

Rennenberg H, Wildhagen H, Ehlting B (2010) Nitrogen nutrition of poplar trees. Plant Biol 12(2):275291. https://doi.org/10.1111/j.1438-8677.2009.00309.x

Richardson J, Isebrands JG, Ball JB (2014) Ecology and physiology of poplars and willows. Poplars and willows - trees for society and environment. CAB International and FAO, Oxforshire, pp 92-123

Schildbach M, Wolf H, Hartmann K-U (2012) Untersuchungen zur abiotischen Resistenz schnellwachsender Baumarten, in: Züchtung Und Ertragsleitung Schnellwachsender Baumarten Im Kurzumtrieb. Nordwestdeutsche Forstliche Versuchsanstalt, Hann. Münden, Germany, pp. 237-257 
Schmidt PA, Glaser T (2009) Kurzumtriebsplantagen aus Sicht des Naturschutzes. In: Anbau Und Nutzung von Bäumen Auf Landwirtschaftlichen Flächen. Wiley Verlag, Weinheim

Seidel D, Beyer F, Hertel D, Fleck S, Leuschner C (2011) 3D-laser scanning: a non-destructive method for studying above-ground biomass and growth of juvenile trees. Agric For Meteorol 151:1305-1311

Seidel D, Hoffmann N, Ehbrecht M, Juchheim J, Ammer C (2015) How neighborhood affects tree diameter increment-new insights from terrestrial laser scanning and some methodical considerations. For Ecol Manag 336:119-128

Stanturf JA, van Oosten C (2014) Operational poplar and willow culture. Poplars and willows: trees for society and the envrionment. CABI/FAO, Oxfordshire, pp 200-257

Stettler RF, Bradshaw HD (1996) Part I. Evolution, genetics, and genetic manipulation. In: Stettler RF, Bradschaw HD Jr, Heilman PE, Hinckley TM (eds) Biology of Populus. NRC Research Press, National Research Council of Canada, Ottawa

Veste M, Böhm C, Quinkenstein A, Freese D (2013) Biologische Stickstoff-Fixierung der Robinie. AFZDerWald 3

Vítková M, Müllerová J, Sádlo J, Pergl J, Pyšek P (2017) Black locust (Robinia pseudoacacia) beloved and despised: a story of an invasive tree in Central Europe. For Ecol Manag 384:287-302. https:// doi.org/10.1016/j.foreco.2016.10.057

von Wühlisch G (2016) Poplars and willows in Germany: report of the National Poplar Commission 20122015. Thünen working paper 38

Publisher's Note Springer Nature remains neutral with regard to jurisdictional claims in published maps and institutional affiliations.

\section{Affiliations}

\section{Jessica Rebola-Lichtenberg ${ }^{1,2}$ (D) Juliane Streit ${ }^{2,3,4} \cdot$ Peter Schall $^{1}$. Christian Ammer ${ }^{1,2}$. Dominik Seidel ${ }^{1}$}

1 Silviculture and Forest Ecology of the Temperate Zones, University of Göttingen, Büsgenweg 1, 37077 Göttingen, Germany

2 Centre of Biodiversity and Sustainable Land Use (CBL), University of Göttingen, Büsgenweg 1, 37077 Göttingen, Germany

3 Division of Agronomy, Department of Crop Sciences, University of Göttingen, Von-Siebold-Str. 8, 37075 Göttingen, Germany

4 Acclimation Dynamics and Phenotyping Group, Department of Molecular Genetics, Leibniz Institute of Plant Genetics and Crop Plant Research (IPK), Corrensstr. 3, Seeland, 06466 OT Gatersleben, Germany 